\title{
Brunei's Sharĩ a Penal Code Order: Punitive Turn or the Art of Non-Punishment?
}

\author{
Dominik M. Müller \\ FAU Erlangen-Nuremberg
}

\begin{abstract}
In his essay, Dominik M. Müller takes an historical approach. He traces Brunei's new Islamic criminal code back to the country's independence in 1984, and even further, to the so-called Anglo-Mohammadan law established by the British protectorate earlier in the twentieth century, and to the Hukum Kanun Brunei before that-some version of which may have stretched all the way back to Islam's arrival to Borneo in the fifteenth century. Müller is the first to assess the Code based on the evidence, albeit from Phase One. From 2014 to 2019, Phase One saw some application of the new Islamic Code to misdemeanors, but the degree paled in comparison with applications of the existing state Code. Looking at a twelve-month period from 2015 to 2016, Müller counts a total of 247 prosecutions under the new Code, all including fines (with the corporal punishments of the new code from Phases Two and Three not yet in effect). He puzzles over the expressions of surprise among the international media outlets at the new Code, given the long history that preceded as well as the legislative history that followed the phased introduction of the new law announced in 2013, and the minor penalties since. Müller then contrasts the international criticism with the local response: feeling under attack, an educated elite and other social media influencers in Brunei closed ranks in support of the new Code under the banner \#BruneiUnited. For Müller, while none of these developments should have surprised the world, the fact that they did likely follows from the fact that Brunei is both historically relatively insular and the "academically most understudied Southeast Asian country." If true, his observation underscores the extent to which more research is required.
\end{abstract}

* I wish to thank Intisar Rabb for inviting me to contribute to this Forum. Her comments and the Journal of Islamic Law's editorial assistance have been tremendously helpful in improving earlier versions of this essay. 


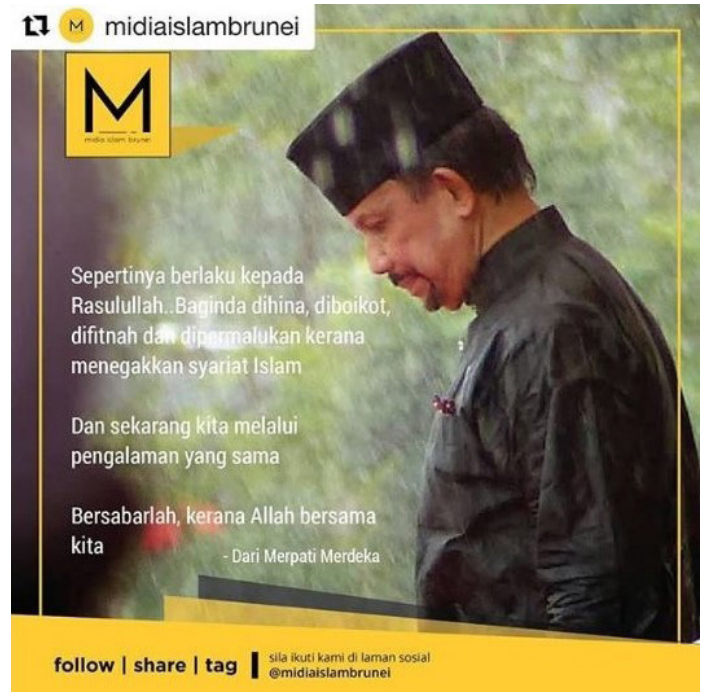

Image circulating on Bruneian social media, comparing criticism against the SPCO with the Prophet Muhammad: "He was insulted, boycotted, slandered, and ashamed for upholding the Sharia-now we are going through the same experience."

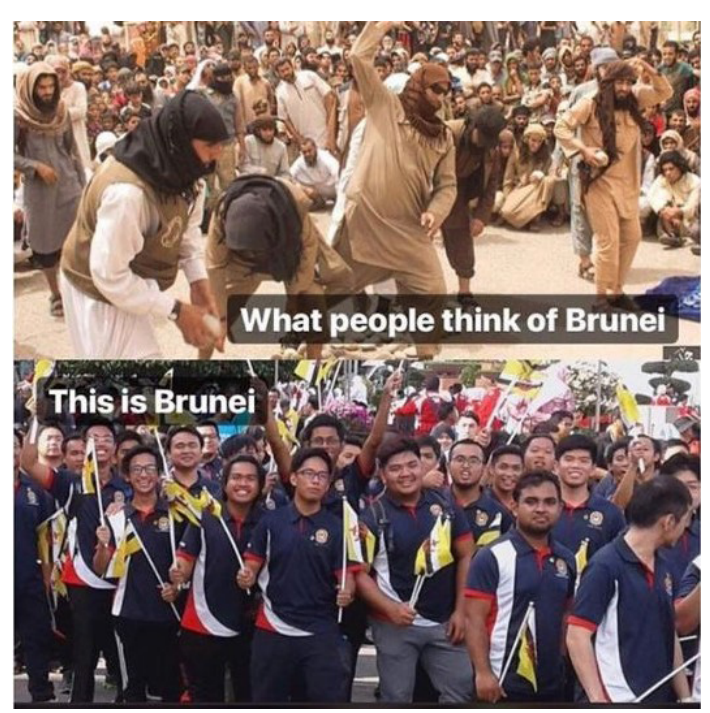

Meme circulating on Bruneian social media, using the hashtag “\#BruneiUnited." April 2019.
BeKunyanyang @BeKunyanyang - 12. Apr.

Gays stoned to death in Brunei? What a hoax!leaping on the bandwagon with all those ignorant celebrities and mass media, with lil or no knowledge, is distasteful. Understand the law. Read the checklist. \#istandwithbrunei \#welovebrunei \#welovehismajesty

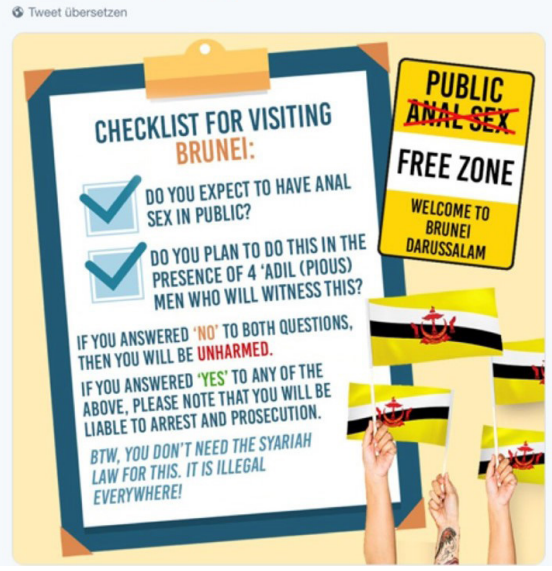

Image circulating on Bruneian social media: "Gays stoned to death in Brunei? What a hoax!" April 2019. 


\section{BRUNEI'S SHARIA REFORM: GETTING THE FACTS Right}

International media coverage exhibited a regrettable lack of knowledge about Brunei and its legal reform. ${ }^{1}$ Most journalists approaching me knew close to nothing about Brunei society, its legal landscape, its domestic politics, or the governmentally prescribed national ideology Melayu Islam Beraja (officially translated as "Malay Islamic Monarchy," commonly referred to by its acronym "MIB"). ${ }^{2}$ This lack of knowledge resulted in the peculiar question, "Why did the Sultan suddenly decide to implement

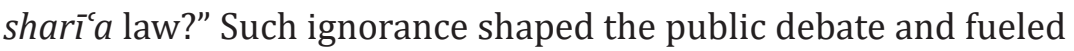
frustrated counter-reactions against international protests. ${ }^{3}$ Con-

1 On Phase One of the legal reform, implemented in May 2014, see, for example, Andrew Buncombe, International Outcry as Brunei Introduces Sharia Law and Takes Country Back to the Dark Ages, InDEPendent (Apr. 30, 2014), https:// www.independent.co.uk/news/world/asia/international-outcry-as-brunei-introducessharia-law-and-takes-country-back-to-the-dark-ages-9308088.html [https://perma. cc/8VMR-KBHL] (with a headline claiming that Brunei "introduce(s) sharia law," despite Islamic law having long existed in Brunei); Eyder Peralta, Sultan of Brunei Introduces Sharia Law, NPR (Oct. 22, 2013), https://www.npr.org/sections/thetwo-way/2013/10/22/240012174/sultan-of-brunei-introduces-sharia-law [https://perma.cc/Q3SD-QZR9] (mistakenly claiming that Brunei had become "the first Southeast Asian country to institute Sharia Law at a national level"); Lucy Westcott, Brunei Becomes First Asian Country to Impose Nationwide Sharia Law, AtLantic (Apr. 30, 2014), https://www.theatlantic.com/international/archive/2014/04/brunei-becomesfirst-asian-country-to-impose-nationwide-sharia-law/361458/ [https://perma.cc/ Z2W2-KLNY] (reiterating the NPR statement). On Phases Two and Three, which took effect in 2019, see Brunei Regresses to Stone Age Laws, Eur. Diplomatic (Mar. 29, 2019), https://europediplomatic.com/2019/03/29/brunei-regresses-to-stone-agelaws [https://perma.cc/B2FD-NJUR] (repeating a popular journalistic "stone age" trope and claiming that "any individuals found guilty of the offenses will be stoned to death publicly" even though that conclusion is in fact contrary to the letter of Brunei's new law); Hollie McKay, Brunei's Crackdown on Homosexuality: Why Kingdom Is Implementing Draconian Sharia Law, Fox News (Apr. 2, 2019), https://www.foxnews.com/world/bruneis-crackdown-on-homosexuality-why-kingdom-is-implementing-draconian-sharia-law [https://perma.cc/553C-YGWU] (reporting on "the Islamic Penal Code known as Sharia Law" and quoting an "expert" warning that "[t]he radical Islamic ideology behind the law can rapidly turn into mass executions").

2 See Dominik M. Müller, Hybrid Pathways to Orthodoxy in Brunei Darussalam: Bureaucratised Exorcism, Scientisation and the Mainstreaming of Deviant-Declared Practices, 37 J. CurRent Southeast Asian AfFs. 141, 150-83 (2018).

3 Every journalist and NGO representative from the United States, United Kingdom, Italy, Germany, and Singapore who approached the author repeatedly asked this question. Some of the most common, purely speculative answers they themselves 
versely, many, including highly educated, cosmopolitan Bruneians, perceived "our Sultan and sovereignty" to be "under attack." They used hashtags like \#BruneiUnited on Instagram and Twitter, ${ }^{4}$ and repeatedly indicated that Brunei was being fundamentally misrepresented and misunderstood by the (non-Muslim) world.

\section{a. A Short History of the Reform, 1996-2013}

The legal reform was no sudden decision. Sultan Hassanal Bolkiah first declared on May 19, 1996, that Brunei should have an Islamic penal code. State-Islamic elites have long lobbied for it, behind the scenes and publicly. They have also successfully pushed forward many other "Islamization" policies since the $1990 \mathrm{~s}^{5}$

In 2011, following a meeting of the authoritative Brunei Islamic Religious Council (Majlis Ugama Islam Brunei (MUIB)) headed by the Sultan, he affirmed the plan, rhetorically asking,

suggested (and others wrote) included indications that "oil reserves begin to decline" (Holly Robertson, Brunei Enacts Islamic Laws to Punish Gay Sex with Stoning to Death, ABC News (Apr. 3, 2019), https:/www.abc.net.au/news/2019-04-03/bruneiintroduces-sharia-law-lgbt-whipping-stoning-to-death/10959618 [https://perma.cc/ J39S-L4BC]); that the Sultan was attempting "to clean up his family's image" (Rebecca Wright, Is the Sultan of Brunei Imposing Sharia Law to Clean Up his Family's Image?, CNN (Apr. 9, 2019), https://www.cnn.com/2019/04/09/asia/brunei-sultan-intl/index.html [https://perma.cc/ZE4G-ERZT]); and other comments that Brunei might be manipulated by Saudi Arabia or that its leader wanted to please Middle Eastern countries for business-related purposes.

4 See, e.g., \#bruneiunited, InstaGRAm, https://www.instagram.com/explore/tags/bruneiunited (last visited Apr. 23, 2020) [https://perma.cc/R5DN-5PXG]; \#bruneiunited, TwiTTER, https://twitter.com/hashtag/bruneiunited (last visited Apr. 23, 2020) [https://perma.cc/7S7A-JMED].

5 In 1990, a working group, following up on an earlier "Committee of Harmonising Laws in Accordance with Islam” (see AwANG AbDul AzIZ BIN Juned, The King who Shapes History: A Tribute in Conjunction with the Golden Jubilee OF THE KING's AsCENSION TO THE THRONE 215 (2017)), began examining all existing laws to bring them "in line with Islam" (see Dominik M. Müller, Sharia Law and the Politics, supra note 5, at 327-45; Dominik M. Müller, Islamic Authority and the State in Brunei Darussalam, in Islamism in Southeast Asia: Kyoto Review of Southeast Asia (Special Issue) 23 (Joseph Chinyong Liow ed. 2018). As Black puts it, since the 1980s, the government has stressed its "commitment to making the Islamic (legal) system the most effective system in the country," and it gradually widened the jurisdiction of Islamic courts to comprise and traverse fields such as family law, adoption, evidence, arbitration mechanisms, and banking and finance. See Ann Black, ADR in Brunei Darussalam: The Meeting of Three Traditions, 4 ADR Bull. 107, 108 (2002); compare Müller, Sharia Law and the Politics, supra note 5, at 321. 
"Who are we to say 'wait'?"6 (much cited7 by Islamic penal code advocates in neighboring Malaysia), and stressing his duty as ruler of an Islamic state to enforce such a code. He unambiguously stated that "only when Islamic laws are in place...can [Brunei] be called 'baldatun tayyibatun wa Rabbun Ghafür,', or a good nation-we have no option but to obey all of Allah's commandments, this is our highest obligation!" He asked again: "Who are we, in the face of Allah [to say] 'no' or 'wait'?!" and later added, "We cannot wait any longer..., we have the capability (kemampuan) and power (kuasa) to do it!"9 On October 22, 2013, in another locally very prominent speech, he declared the code's finalization-still largely unnoticed in the international media.

This sentiment was neither new nor idiosyncratic to the

6 See Hajah Zabaidah \& Haji Salat, Jangan kata "Tidak" atau "Tunggu Dulu" (Don't Say "No" or "Wait First" (author's translation)), Pelita Brunei (Oct. 15, 2011); Who Are We to Say “Wait," Brunei Times (Oct. 13, 2011). The State Muftī, one of the SPCO's key architects, printed the Sultan's statement preceding that rhetorical question in the same speech, stating, "We cannot wait any longer or say "wait first"' (kita tidak boleh lagi berkata tidak atau tunggu dulu), on the cover of a book of poems lauding the SPCO, authored by himself (published under his pen name). See Adi Rumi, Perintah Kanun Jenayah Syari'ah: "Neraca Allāh" (2013).

7 The news became widely shared in social media, for example, by supporters of the Pan-Malaysian Islamic Party (Parti Islam Se-Malaysia (PAS)), about whom I conducted ethnographic research at that time. Prominent Malaysian preachers like Ustaz Azhar Idrus ("UAI") lauded the Sultan for fulfilling his "duty" while critically contrasting it with Malaysia "opposing God's Law." See Ustaz Azhar Idrus, Pandangan Tentang Hudud Di Brunei 31.12.2013 - Ustaz Azhar Idrus, YouTuBE (Dec. 31, 2013), https://www.youtube.com/watch?v=f1P-qc2BJ_4 [https://perma.cc/ U7JD-UKQT]. For one of the many blogs that enthusiastically carried the news, similarly noting contrasts between the Sultan of Brunei as exemplary and the then-Malaysian Prime Minister Najib Tun Razak as not for refusing to implement hudūd laws, see Cer Citer. Cer Citer.., (Feb. 15, 2012), http://ezwankini.blogspot.com/2012/01/ baginda-sultan-brunei-juga-yang_15.html [https://perma.cc/F6HC-SU4K]. On the Bruneian legal reform's cross-border impacts, see also Dominik M. Müller, Paradoxical Normativities in Brunei Darussalam and Malaysia: Islamic Law and the ASEAN Human Rights Declaration, 56 Asian SuRvey 415, 437-39 (2016).

8 A Qur' ānic expression, translatable as a "prosperous country blessed by the Almighty God Allah" (Qur'ān, 34:15). This translation was taken from HAEDAR Nashir, MuHAmmadiyah: A Reform Movement 101 (2015).

9 A video of the Sultan's speech, held at the opening ceremony of a Seminar on Islamic Law (Seminar Antarabangsa Perundangan Islam), which shows him explaining - with English subtitles - the SPCO as an instrument to realize the notion of "baldatun thayyibatun wa rabbun ghafur," is available at https://www.youtube.com/watch? $\mathrm{v}=\mathrm{ES} 4$ ifVH1E8Q [https://perma.cc/VES9-W6ZN]. It is also cited in Zabaidah \& Salat, supra note 6, at 2. 
person of the Sultan. Prominent state-Islamic advisors, like State Muftī Awang Abdul Aziz bin Juned (a key architect of Bruneian state-Islam), the late Mahmud Seadon Othman (who already in the 1990s proposed to abandon all non-sharí ${ }^{\top} a$ legislation and have an Islamic penal code), and Anwarullah Shafiullah (originating from Pakistan), have always promoted this narrative. They did so mostly behind the scenes (where Islamic policies in Brunei are normally lobbied for, drafted, and introduced "internally..., slowly and quietly"10), though they regularly also did so in public and in local Bruneian Malay-language publications. ${ }^{11}$ In the absence of an opposition or independent civil society, the Islamic bureaucracy is among Brunei's most powerful political forces. ${ }^{12}$ Some wonder whether the absolute monarch controls them, or they control him, and the truth probably lies somewhere in between.

\section{b. Phased Implementation, 2014-2019}

On April 3, 2014, implementation of the Syariah (Shari ${ }^{-} a$ ) Penal Code Order 2013 (SPCO, or Perintah Kanun Hukuman Jenayah Syariah 2013) began, announced to unfold in three stages. In a speech, with key royal family and government members sitting on stage, symbolizing undivided support, the Sultan noted his fulfillment of an unquestionable divine obligation, and said that state-Islamic agencies would now be tasked with implementing the law "with full responsibility."13 Not only were international

10 Iik Arifin Mansurnoor, Islam in Brunei Darussalam and Global Islam: An Analysis of Their Interaction, in IsLam In the ERA of Globalization: Muslim AtTitudes Towards Modernity and IDENTITY 71, 88 (Johan Meuleman ed., 2002); Müller, supra note 2, at 153; Müller, Sharia Law and the Politics, supra note 5, at 327.

11 See, e.g., Anwarullah, Criminal Law of Islam (2015); Mahmud Saedon Othman, Jejak-Jejak: Kumpulan kertas kerja Allahyarham Dato Paduka Seri Setia Profesor Dr. Haji Awang Mahmud Saedon bin Awang Othman (2003); Mahmud Saedon Othman, Perlaksanaan dan Pentadbiran Undang-Undang Islam di Negara Brunei Darussalam: Satu Tinjauan (1996); Mahmud Saedon Othman, A Review on the Implementation and Administration of IsLamic Law in Brunei Darussalam (2008); Experts Laud Brunei for Introducing Syariah Law, Borneo Post (Oct. 25, 2013), https://www.theborneopost.com/2013/10/25/experts-laud-brunei-for-introducing-syariah-law [https://perma.cc/F9ZP-ZC2T].

12 Müller, Sharia Law and the Politics, supra note 5, at 320.

13 The original Malay wording is: "terutama agensi-agensi yang berkaitan, 
media outlets surprised, but also many Bruneians who had not followed Sharia-related royal decrees and discourses before, were caught by surprise. ${ }^{14}$ American celebrities, concerned about animus against homosexuals, staged protests at the Beverly Hills Hotel. For example, Fox News TV aired a segment in 2014, using the slogan, "Welcome to the Hotel Sharia-you can check in, but you can never leave."15 But the media caravan soon moved on.

Phase Two was scheduled to begin twelve months after an additional procedural code had been finalized. The completion of the Syariah Courts Criminal Procedure Code Order (SCCPCO) was initially said in 2014 to take six months. But it was only finalized much later, in March 2018. Some mistakenly speculated about the SPCO's "postponement"; ${ }^{16}$ others assumed that it was "abandoned" due to international pressure. ${ }^{17}$ The Sultan, meanwhile, publicly criticized the Ministry of Religious Affairs and Attorney General's Chambers in 2016 for the SCCPCO's slow progress, warning that delays could make the legal reform look "worthless." ${ }^{18}$ He repeatedly noted that the world would misunderstand the law, but that its purpose was "not to look left and right in search for anyone who

hendaklah melaksanakannya dengan penuh tanggungjawab." See Sultan Haji Hassanal Bolkiah's Royal Address (Titah Sempena Majlis Pengisytiharan Penguatkuasaan Perintah Kanun Hukuman Jenayah Syar'iah 2013) (Apr. 30, 2014).

14 This note is based on my personal observation from conversations with Bruneians at that time and later, in retrospect.

15 Welcome to the Hotel Sharia, Fox News TV (May 10, 2014), https:// archive.org/details/FOXNEWSW_20140510_100000_FOX_and_Friends_Saturday/ start/1206/end/1266 [https://perma.cc/754N-8ZCB]. See also Meena Jang, Jay Leno Joins Feminists at Beverly Hills Hotel Protest: “What Year Is It, 1814?," HollyWOOD REPORTER (May 5, 2014), https://www.hollywoodreporter.com/news/jay-lenojoins-feminists-at-701320 [https://perma.cc/852K-YFYV].

16 Already in his 2014 speech, the Sultan stressed that "there is no question at all that we are postponing the order's enforcement as quoted by media" (translation), responding to articles like Brunei Postpones Tough New Islamic Law, BBC News (Apr. 23, 2014), https://www.bbc.com/news/world-asia-27122016 [https://perma.cc/7V4X-QJFM].

17 This assessment is based on personal conversations with various interested parties between 2016 and 2018. See also Rui Hao Puah, Brunei's Sharia Dilem$m a$, COGITASIA (CSIS Asia Program, Center for Strategic \& International Studies) (Sept. 25, 2015), https://www.cogitasia.com/bruneis-sharia-dilemma [https://perma. cc/G4J2-GV9U].

18 For further discussion, see Müller, supra note 7, at 203. 
likes or dislikes it, but to fulfill Allah's commandments"19 (mirroring the State Muftì's long-expressed view that non-Muslims could by definition not "understand Islam" and naturally "oppose" it, implying assumed wider agendas to "colonize" Muslim minds) ${ }^{20}$ Throughout this period (2014-2018), Brunei's state-controlled media, and the State Muftī, constantly referred to the SPCO as a symbol of historically deep-rooted national identity and tradition under the "national ideology" of Melayu Islam Beraja (MIB). The daily evening news on Radio Television Brunei (RTB) presented one "beautiful" SPCO section per day to educate the public. Trainings, the establishment of a diploma program in Islamic Criminal Justice at Brunei's Sultan Sharif Ali Islamic University, and preparatory international exchanges took place. ${ }^{21}$ The Sultan also noted

19 For example, in the speech marking the inauguration of the SPCO on April 30, 2014, he noted that "my personal obligation and our obligation to Him in enforcing Islamic Laws, have already been accomplished (by enforcing the SPCO)," and added, "Remember, our focus is on Allah alone, to seek his blessings, and not looking left and right in search of anyone who likes or dislikes it [the SPCO]. ... Allah's commandments are not a theory, but obligatory law...as prescribed by the Quran and Sunnah." Sultan Haji Hassanal Bolkiah, Enforcing Shariah Law - Golden Speech of Sultan of Brunei. May 1st, 2014, YouTube (Apr. 30, 2014), https://www.youtube. com/watch? $\mathrm{v}=\mathrm{Vjv} 3 \mathrm{~b} \_Z d$ ic [https://perma.cc/5LFE-Z9BQ], minutes 3:35-3:50, 4:10-5:31 (author's translation). In his SPCO-related speech on October 13, 2011, he said, "[W]e have no option but to obey all of Allah's commands, this is our highest duty. One of His commands is to implement His laws. These are Sharia laws." Sultan Haji Hassanal Bolkiah, Ucapan Sultan Brunei Berkaitan Hukum Hudud - MalaysiaBerih, YouTube (Oct. 13, 2011), https://www.youtube.com/watch?v=19hW_Aw8rho [https://perma.cc/H9Q9-4VAX], minutes 1:02-1:25 (author's translation). In yet another speech, in October 2013, the monarch stressed the implementation of Islamic law was meant to ensure blessings for the afterlife (Arabic: ākhira; Malay: akhirat), as "promised" by Allah, against which factually questionable arguments of potential economic disadvantages would have no value. See Sultan Haji Hassanal Bolkiah, Titah Baginda Sultan Brunei : Perlaksanaan Syariat, YouTuBe (Oct. 11, 2013), https:// www.youtube.com/watch? $v=r H Q a Q g 7 w 8 P M \quad[h t t p s: / / p e r m a . c c / 3 J 3 N-K D Y V]$. For the State Muftī's writings on Brunei's Islamization policies as "hereafter investments," see ABDUl AzIz JUNED, supra note 5, at 310, 315.

20 This sentiment was expressed, for example, in a televised lecture from 2014. See Müller, supra note 2, at 325. Similarly, the prominent MIB interpreter cited in the same context Qur'anic verse (2:120) stating that "never will the Jews or the Christians approve of you until you follow their religion," to advise that Bruneians should thus "stop being apologetic" while "making the implementation of Islamic law our top priority at all levels." See Abdul Latif Ibrahim, Melayu Islam Beraja: Suatu Pemahaman xix, 109 (2013).

21 See Dominik M. Müller, Brunei Darussalam in 2016: The Sultan Is Not 
that the SPCO might create (generally lacking) new jobs for Islamic Studies graduates. ${ }^{22}$

Before 2019, the SPCO's Phase One (Arabic: $t a^{\circ} z i \bar{r}$; Malay: takzir) was applied in some cases, but much fewer than the regular penal code. According to local media reports, a cross-dresser, for example, was sentenced to a monetary fine in $2015,{ }^{23}$ and another cross-dresser was arrested and charged under the SPCO in 2016. ${ }^{24}$ In total, 247 Sharî $^{-}$a offenses were reportedly prosecuted in the fiscal year 2015-16, none including corporal punishments, as SPCO sections enabling these more severe punishments (h̆udüd/ qișāss) would become enforceable only in Phases Two and Three. ${ }^{25}$

In April 2019, one year after the SCCPCO was presented and thus on schedule, the SPCO's next phase followed. Again, the world was strangely caught by surprise, as indicated by the reactions of representatives from international news media outlets, human rights organizations, and otherwise well-informed parties, and as also indicated by the reactions of many Bruneians, including members of the LGBTQ community as well as government officials working outside of the Islamic bureaucracy (as observed by the author, partly through personal exchanges). But the only real surprise was that Phases Two and Three were enforced together, counterbalancing the SCCPCO's prior delay. The SCCPCO's draft was already near-complete in 2016, and in my personal interviews those involved gave no clear explanation as to why its finalization took two more years. In 2014, the authorities stated that the phased implementation would allow the public to "get

Amused, 57 Asian Survey 199, 204 (2017).

22 Id.

23 See Ak Md Khairuddin Pg Harun, Bruneian Civil Servant Fined \$1,000 for Cross-Dressing, BRunei Times (Mar. 11, 2015), https://btarchive.org/news/national/2015/03/11/bruneian-civil-servant-fined-1-000-cross-dressing [https://perma.cc/ TC36-RBDU].

24 See Cross-Dresser Arrested During Joint Operation, Borneo Bull. (Aug. 16, 2016).

25 For citations and further discussion, see Müller, Brunei Darussalam, supra note 21, at 204. See also Khai Zem Mat Sani, MoRA, AGC Finalising Syariah Courts Criminal Procedure Code, Brunei Times (Mar. 15, 2016), https://btarchive. org/news/national/2016/03/15/mora-agc-finalising-syariah-courts-criminal-procedure-code [https://perma.cc/F4WC-6RTY]. 
used" to the SPCO. ${ }^{26}$ This sentiment might partly explain the SCCPCO's delay, as would initially underestimated logistical challenges, and potentially some parties' reluctance to take responsibility-a hiccup to which the monarch himself alluded in his 2016 speech criticizing the delay. ${ }^{27}$

\section{c. International Controversy and the Death Penalty Moratorium, May 2019}

The beginning of Phases Two and Three was met by massive international protests. These protests were amplified by the involvement of Hollywood celebrities-which I dub the "Clooney effect" to refer to George Clooney's public stance against the bill. ${ }^{28}$ Human rights advocacy groups protested as well. ${ }^{29}$ The Brunei Project, run by the Australian human rights activist Matthew Woolfe, has been particularly influential and widely present in different media outlets, having been the first voice in March 2019 to make international audiences aware of Brunei's imminent plans to enforce the SPCO's Phases Two and Three. ${ }^{30}$ The European Union in 2019 considered various consequences, and several multinational companies and banks declared publicly they would reconsider their business relations with Brunei. ${ }^{31}$

In response, on May 5, 2019, the Sultan publicly stated

26 See Müller, supra note 2, at 324; see also Quratul-Ain Bandial, Implementation of Syariah Law, BRUNeI Times (Dec. 15, 2014), https://btarchive.org/news/ national/2014/12/15/implementation-syariah-law [https://perma.cc/CY7Y-G6U9].

27 Müller, supra note 21, at 204.

28 See Ben Westcott, George Clooney Calls for Hotel Boycott over Brunei LGBT Death Penalty, CNN (Mar. 30, 2019), https://www.cnn.com/2019/03/29/asia/ george-clooney-brunei-lgbt-intl/index.html [https://perma.cc/LT6Q-2HRZ].

29 See, e.g., Brunei: New Penal Code Imposes Maiming, Stoning; Immediately Suspend Highly Abusive Law, Human Rights Watch (Apr. 3, 2019), https:// www.hrw.org/news/2019/04/03/brunei-new-penal-code-imposes-maiming-stoning [https://perma.cc/CDX6-TRN5].

30 See various SPCO-related entries since March 2019 on The Brunei Project, FАСЕвоOK, https://www.facebook.com/thebruneiproject [https://perma.cc/J99E4TSM].

31 Emily Dixon, More Companies Boycott Brunei over Anti-Gay Laws, CNN (Apr. 5, 2019), https://edition.cnn.com/2019/04/05/asia/brunei-hotel-airline-boycott-scli-intl/index.html [https://perma.cc/682B-DSBN]. 
what government representatives had long stressed (albeit never said publicly), ${ }^{32}$ and what many Bruneians equally assumed: that Brunei's "de facto moratorium on the death penalty" would continue under the SPCO. ${ }^{33}$ This statement was not the "dramatic U-turn" that the international media claimed it to be, grounded in their own previous claims about the SPCO. ${ }^{34}$ Content-wise, the Sultan's statement was not surprising, but his explicit declaration was. He explained, once again, responding to foreign "misconceptions" ("salah tanggapan"), while clearly aiming to counter massive international pressures targeting Brunei's economic interests. $^{35}$

Even though it did not in fact present a media-proclaimed rupture from past practice, the explicit statement of a moratorium on the death penalty has changed the landscape of controversy surrounding Brunei's new Islamic criminal code. It reduces the risk of the law developing a life of its own in the hands of potentially zealous enforcers. Affected individuals, for example, ex-Muslims or LGBTQ persons, may not feel appeased..$^{36}$ The Van-

32 Bruneian authorities avoid speaking with international media on "sensitive" issues - which most political and religious matters are considered (except where a higher authority's pre-existing official position is supportively reproduced, but in shari ${ }^{\prime} a$-related matters not even then). This systemic silence contributes to the poor quality of international understanding and media coverage of Bruneian state and society, and deepens the very misunderstandings that the Sultan has repeatedly pointed out and that Bruneian social media voices rightly complain about.

33 Hajah Siti Muslihat Haji Salleh \& Haniza Abdul Latif, Undang-undang Jenayah Syariah penuh rahmat, Pelita Brunei (May 5, 2019).

34 See Maya Oppenheim, Brunei Says It Will Not Enforce Death Penalty for Gay Sex in Dramatic U-Turn After Widespread Criticism, INDEPENDENT (May 5, 2019), https://www.independent.co.uk/news/world/asia/brunei-death-penalty-gaysex-law-stoning-sharia-sultan-hassanal-bolkiah-a8900636.html [https://perma.cc/ PNB4-4992]. See also Brunei Says It Won't Enforce Death Penalty for Gay Sex, BBC News (May 6, 2019), https://www.bbc.com/news/world-asia-48171165 [https://perma.cc/T8RH-YQFU] (speaking of a "rethink" and Brunei having "backtracked").

35 The full speech, on the occasion of the beginning of the fasting month of Ramadan, is available at Titah Sultan Brunei Sempena Menyambut Bulan Suci Ramadhan 1440h, YouTuBe (May 5, 2019), https://www.youtube.com/watch?v=gkfTiqiknik [https://perma.cc/5B8X-GGES].

36 This note is based on personal interviews with a Bruneian ex-Muslim of non-normative gender orientation and a Bruneian homosexual in exile in Vancouver, May 2019. Personal communication with Shahiran Sheriffuddin Shahrani Muhammad, in Vancouver, Canada (May 7, 2019). 
couver-based political refugee Shahiran Shahrani, for example, who faced sedition charges for insulting the Ministry of Religious Affairs over halāl regulations on his private Facebook page, responded that a statement that the Sultan does not explicitly frame as "definite royal decree" is not binding, even if it is made within a royal speech (titah). He called it a "clever complicated ploy" that would leave various options on the table for his successor to the throne. He also pointed to what he considered to be the new law's many other human rights-violating provisions beyond the death penalty. ${ }^{37}$

The moratorium statement was remarkable also considering that the SPCO's key propagator, State Muftī Awang Abdul Aziz Juned, had not long ago criticized earlier (pre-SPCO) calls among state institutions other than his own to formalize the long-existing de facto moratorium into a de jure moratorium. ${ }^{38}$ The Muftī expressed this criticism, ${ }^{39}$ somewhat ironically, in a book ostensibly about the Sultan. ${ }^{40}$

Furthermore, the Sultan's declaration of such a moratorium now is striking for internal government dynamics in Brunei, considering the Muftì's otherwise extensive powers in any shari ${ }^{-} a$-related policy matters. ${ }^{41}$ For two decades, the Sultan appears to have always consented to the recommendations of the Islamic bureaucracy's elites-the SPCO's very existence and de-

37 For a comprehensive overview of human rights violations, see Brunei Darussalam, in Keeping the Faith: A Study of Freedom of Thought, ConSCIENCE, AND ReLigion In ASEAN 55 (David Cohen \& Kevin Tan eds., 2015). The remainder is based on my May 2019 interview with Shahiran Sheriffuddin Shahrani Muhammad, and a digital follow-up correspondence for clarification on August 9, 2019.

38 See Abdul Aziz JunEd, supra note 5, at 199-203.

39 Among other categorical statements contradicting an explicitly declared moratorium, the State Muftī wrote, "Imagine if the death penalty is abolished, does that not give a signal that encourages people to kill? There is nothing to fear anymore because the penalty for killing is no longer death. Who will fear killing one another if the penalty is merely a fine or imprisonment?" ABDUL AzIz JUNED, supra note 5, at 202.

40 This very interesting book, The King Who Shapes History (see Abdul AzIZ JunED, supra note 5), in my reading however says more about the Islamic bureaucracy's political achievements than about the actual person of the Sultan.

41 See Müller, supra note 2, at 154-55. 
sign being a case in point. Regrettably, there is no known research on such intra-state dynamics, government institutions' workings behind closed doors, their implications for Islamic policymaking, or their societal consequences. Bruneian government representatives, would, understandably, claim "harmony" and that they share a monolithic, unified stance when they speak to outside audiences (if they speak to them at all). They also customarily adhere to a strict code of secrecy, while state-controlled media provide zero space for any such political analysis. These elements make research on Islam-related (and any other) politics in Brunei a highly challenging endeavor, but they also illustrate an urgent need to enable more grounded and adequate understandings of local developments.

Although international media have largely failed to provide any substantial insights, accessing local knowledge about Islamic (or any other) policymaking in Brunei is admittedly a challenging endeavor, as Brunei presents arguably the academically most understudied Southeast Asian country. Rising to the challenge will require a lot of trust-building for foreign scholars and journalists alike, if they/we want to gradually change the current status quo. It will only be possible through respectful epistemic partnerships. For the Brunei government, opening its iron gates at least a little might serve its own interests, as doing so could enable the world to gain a more realistic picture than that of some of the orientalist caricatures that have emerged from the current wave of protests and calls for boycotts or sanctions.

\section{Situating Brunei's Sharī'a Reform: Punitive TuRn OR THE ART OF NON-PUNISHMENT?}

Contrary to international media language, Brunei has not recently decided to "implement Sharia Law," in the words of ABC 
News among others. ${ }^{42}$ It has transformed an existing sharī $` a$ judiciary, which mainly addressed family law, but also presided over

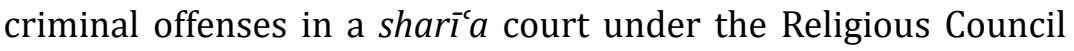
and Kadis Courts Act of 1984 (Akta Majlis Ugama Islam dan Mahkamah Kadi Penggal 77). ${ }^{43}$ Codifying and prosecuting sharī‘ $a$ offenses in Brunei dates back to Anglo-Muhammadan colonial laws, beginning in the early twentieth century. ${ }^{44}$ Before that, an Islamically inspired code, called the Hukum Kanun Brunei, was in place, to which government authorities today questionably refer when claiming that the SPCO would restore a centuries-old Bruneian "tradition" of enforcing Islamic criminal law. ${ }^{45}$

42 See Kanaha Sabapathy, Brunei Set to Implement Sharia Law, ABC News (Apr. 24, 2014), https://www.abc.net.au/news/2014-04-24/an-brunei-sharia-law-enactment/5410588 [https://perma.cc/6SU6-SYYD].

43 The MUIB is de jure the "chief authority" in "all matters relating to religion." Religious Council and Kadis Courts Act $\S 38$ (1984) (as amended) [hereinafter RCKCA], http://www.agc.gov.bn/AGC\%20Images/LAWS/ACT_PDF/cap077. pdf [https://perma.cc/M25Z-73ZS]. This official belongs to the Ministry of Religious Affairs. Müller, supra note 2, at 153.

44 See Timothy Lindsey \& Kerstin Steiner, 3 Islam, Law and the State In Southeast Asia: Malaysia ANd BRunei (2012); Iik Arifin Mansurnoor, Formulating and Implementing a Shari 'a-Guided Legal System in Brunei Darussalam: Opportunity and Challenge, 1 Sosionumanika 219 (2008); Iik Arifin Mansurnoor, Re-establishing Order in Brunei: The Introduction of the British Legal System During the Early Residential Period, 52 Islamic Studies 155 (2013); Müller, supra note 2, at 321.

45 See Mahmud, supra note 11, at 14ff; Kerstin Steiner \& Dominik M. Müller, Pluralism in Brunei's Constitution? Ethnicity, Religion, and the Absolute Monarchy, in Pluralist Constitutions in Southeast Asia 86 (Jaclyn L. Neo \& Bui Ngoc Son eds., 2019). The Sultan adopted this narrative in his speech of May 1, 2014, when he declared the implementation of the SPCO Phase One and stated that Brunei would "repeat its history of Islamic Law that has already been practiced centuries ago in this country." The speech is available at Enforcing Shariah Law - Golden Speech of Sultan of Brunei. May 1st, 2014, YouTuBe (May 2, 2014), https://www.youtube.com/ watch?v=Vjv3b_Zd_ic [https://perma.cc/5LFE-Z9BQ], minutes 2:25-2:30). Regrettably, no substantial historical research exists detailing whether, and if so how, this pre-colonial code, modelled after the more famous Hukum Kanun Melaka (cf. MIchael G. Peletz, Islamic Modern: Religious Courts and Cultural Politics in MaLAYSIA 62 (2002)), has been applied. Very little is known about pre-colonial judicial and policing practices in Brunei, except some colonial anecdotes about provisions in the SPCO era locally discussed about the amputation of a hand in a theft case. See Awang Abdul Aziz bin Juned, Islam in Brunei During the Reign of His Majesty Sultan Haji Hassanal Bolkiah Mu'izzaddin Waddaulah Sultan and Yang Di-Pertuan of Negara Brunei Darussalam, xlix (2008) (original Malay-language publication: 1992); John S. Carroll, Berunai in the Boxer Codex, 55 J. MaLaYsian 
In post-colonial Brunei, the SPCO presents only the latest of many political and legal "Islamization" measures under Brunei's national ideology, Melayu Islam Beraja, that is, of "Malay Islamic Monarchy," as noted above. Since independence in 1984, the government has framed Brunei as a "non-secular" Islamic State (Negara Islam) ${ }_{, 4}^{46}$ and as an "MIB State" (Negara MIB). ${ }^{47}$ For a century, Islamic legislation (originally called "Mohamedan Law") coexisted with the code inspired by British common law: the so-called Civil Law (Undang-Undang Sivil), ${ }^{48}$ which includes the Penal Code of 1951 and which remains in force. ${ }^{49}$ The SPCO does not replace this "civil" Penal Code, and the dual system continues to exist, ${ }^{50}$ with some "hybridizing" modifications. ${ }^{51}$

The pre-SPCO Sharia offenses varied in scope. Some were sexuality related, others protected the state's exclusive authority to interpret and speak publicly about "authentic" Islam. The pre-SPCO laws outlawed "deviant teachings" (ajaran sesat), ${ }^{52}$ and banned pre- and extra-marital sex-both normally resulting in fines (though theoretically punishable with two months' imprisonment). ${ }^{53}$ Childbirth outside of marriage was legally framed as resulting in "illegitimate children," ${ }^{54}$ and "disobedient" behavior of wives was pronounced illegal ${ }^{55}$-even though petitioners rarely

Branch OF THE Royal Asiatic Soc'y 1-25 (1982).

46 Ibrahim, supra note 20, at xxxiv; AbDul LATIF IBRAhim, IsSUes IN BRUNEI Studies 197 (2003); Sharon Siddique, Brunei Darussalam 1991: The Non-Secular Nation, Southeast Asian AfFairs 91-100 (1992).

47 See Müller, supra note 2, at 151.

48 See id. at 154.

49 The Penal Code's English version is available at http://www.agc.gov.bn/ AGC\%20Images/LOB/pdf/Cap22.pdf [https://perma.cc/J375-Y4FW].

50 ABdul AzIz JunED, supra note 5, at 218.

51 See Unique Hybrid Legal System Mooted, Brunei Times (Jan. 5, 2012); Müller, supra note 7, at 426.

52 RCKCA § 186. For a key Bruneian government publication defining and demonizing "deviant teachings" (ajaran sesat), authored by Brunei's current Rector of Sultan Sharif Ali Islamic University (UNISSA), see Norafan Zainal, Perkembangan Ajaran Sesat di Negara Brunei Darussalam (2007). See also Müller, supra note 2, at 153, 328; Müller, Brunei Darussalam, supra note 21, at 424.

53 RCKCA $\S \S 177-78$.

54 RCKCA $\S \S 83,92$.

55 RCKCA $\S 176$. 
brought such cases to court. All of these offenses were punishable with milder sentences than the Penal Code offenses, and only applicable to Muslims. Since around 1990, the Civil Law was systematically reviewed to become "sharī $a$-compliant," in accordance with the state-Islamic authorities' interpretation of the sharī ${ }^{-} a{ }^{56}$ The sale of alcohol and pork was banned in the early 1990 s. $^{57}$ Even certain royal regalia that the State Muftī considered incompatible with Islam, including two golden cats attached to the throne, ${ }^{58}$ were abandoned upon the Sultan's decision..$^{59}$ Frequently mentioning these "divine blessings-generating achievements," the State Muftī considers Brunei's Civil Law not as "secular" but as a manifestation of $t a{ }^{\prime} z i \bar{r}$ laws, that is, discretionary laws that a legitimate Islamic ruler can define and that are therefore counted as a part of Islamic law, or sharī ${ }^{-} a^{60}$

The SPCO presents neither simple continuity nor radical rupture. While it had precursors, it introduces numerous shari $a$ offenses, increases maximum punishments for existing ones, and makes some applicable to non-Muslims. ${ }^{61}$ Although international media and protests focus on LGBTQ matters and the amputation of limbs, the SPCO and SCCPCO are multifaceted documents deserving broader analysis that should address larger human rights implications.

Consider the punishment of stoning for sex crimes outlined in the new law. For homosexual or heterosexual anal in-

56 Laws to Be Brought in Line with Islam, 60 Brunei Darussalam NewsL. 1 (Sept. 1990); Dominik M. Müller, Bureaucratic Islam Compared: Classificatory Power and State-ified Religious Meaning-Making in Brunei and Singapore, 33 J. L. \& ReLIG. 212 (2018); Müller, supra note 2, at 321; Müller, supra note 7, at 426.

57 Müller, supra note 56, at 224.

58 According to the State Muftī's legal reasoning, depicting animals (if their full body is shown) is Islamically forbidden. Having such depictions in a building would furthermore prevent the Angel of Compassion from entering that house. ABDUL AzIz JunED, supra note 45, at 147-48.

59 ABdul AzIz JunED, supra note 5, at 228-45, 349.

60 Abdul Aziz Juned, supra note 5, at 213, 216-17. See also SHerman Jackson, Islamic Law and the State: The Constitutional JuRisprudence of ShiHĀB AL-DīN AL-QARĀFİ (1996).

61 See Müller, supra note 2, at 324; see also the author's comparisons between pre-SPCO and SPCO stipulations for punishments in Brunei Darussalam, supra note 37 , at $62 \mathrm{ff}$. 
tercourse and adultery, stoning is the maximum punishment on paper. It applies to Muslims generally, and to non-Muslims if the act was committed with a Muslim (but see Part I, Section C, on the death penalty "moratorium"). Lesbian sex among Muslims is punishable with up to ten years' imprisonment, or a fine, or whipping, or a combination of all three. The SPCO § 69(2a) states that if the procedural requirements for a hadd-based (fixed criminal law) death penalty are not met, offenders face up to seven years in prison and thirty strokes. In comparison, the British-originating Penal Code (§ 377) punishes these acts with up to ten years' imprisonment. ${ }^{62}$

Several new offenses are socially oriented. Some include cross-dressing (up to one year or a fine, also for non-Muslims, SPCO § 198), causing a married Muslim woman "to leave the matrimonial home determined by her husband" (SPCO § 201), causing a non-married woman "to leave the custody of her parents or her guardian" (also for non-Muslims, SPCO § 202), parents "giving away" a Muslim child to non-Muslims (SPCO § 204), "indecent behavior" (SPCO § 197), "sorcery" and the advertising thereof (SPCO $\S 208$ ), murder by sorcery or attempting to do so (SPCO §§ 151154), and holding traditional presumably deviant beliefs according to which objects possess "healing powers" or "grant wishes" (SPCO § 216) The new law also makes punishable Muslims accusing other Muslims of being infidels (SPCO § 219).

Penalties have increased for some pre-existing offenses. For example, building mosques without permission (previously RCKCA § 124, now SPCO § 240), men not attending Friday prayers (previously RCKCA § 171, now SPCO § 194), and "close proximity" (khalwat) among non-married couples (previously RCKCA § 173; now SPCO § 196) all carry higher maximum punishments.

Particularly remarkable, considering its consequences for both Islamic intellectual reasoning and freedom of thought, conscience, and speech, is how the SPCO further cements the state's exclusive Islamic authority. Questioning hadith considered to be

62 The author is not aware of any case where such a punishment has ever been imposed. 
authentic risks punishment that ranges from lengthy prison terms to the death penalty (SPCO $\S \S 111,222-224$, falling under apostasy and blasphemy charges). Disseminating "beliefs contrary" to the government's interpretation of Islamic law can be punished with up to five years' imprisonment (SPCO § 207), for Muslims and non-Muslims alike, declaring oneself or others to be prophets-Malaysia recently saw such a case (Abdul Kahar Ahmad ${ }^{63}$ )risks death, and if the hadd punishment conditions are not met, up to thirty years (SPCO § 109). For minorities like the Ahmadiyyah or Bahá'i (long banned and condemned as entirely intolerable by the State Muftī for having prophet-like figures as their founders), ${ }^{64}$ this makes their situation even more precarious. Blasphemy risks the same punishments (SPCO $§ § 110,221)$. Owning or distributing publications contradicting state interpretations of Islamic law carries a punishment of up to two years' imprisonment (SPCO §§ 213-215), as does the public teaching of Islam without a permit (SPCO § 229). Also punishable are issuing "illegal fatwas" (three years' imprisonment, SPCO § 228), and collecting or paying religiously mandated alms/taxes (zakat) outside of state channels (two years' imprisonment, SPCO §§ 237-239). Anyone can be imprisoned for inciting a Muslim to neglect "religious duties" (SPCO $\S 199$ ). Non-Muslim missionary work targeting Muslims (SPCO $\S \S 209-211$ ), or telling a Muslim child or a child whose parents have "no religion" to convert to a religion other than Islam, can cause imprisonment (SPCO § 212), as can performing or teaching sharī $a$-violating ceremonies to Muslims (SPCO § 207), or inviting Muslim children to participate in non-Muslim religious activities (SPCO § 212). The government, however, in reaction to protests, repeated its stance that the SPCO is not discriminatory, does not violate anybody's rights, and would protect people's privacy. Many Bruneians wholeheartedly agreed on social media.

It cannot be stressed enough that listing maximum pun-

63 Christina Tan, "Prophet" Gets Ten Years, Star (Petaling Jaya) (Oct. 22, 2009), https://www.thestar.com.my/news/nation/2009/10/22/prophet-gets-10-yearsjail [https://perma.cc/CQ55-LPWR].

64 ABdul AzIz JunED, supra note 45, at 121-25; cf. Müller, supra note 2, at 328 . 
ishments does not do justice to the situation's complexities in light of defendant-regarding procedures. For some offenses, authorities can flexibly decide, case-by-case, whether to apply the SPCO or the old Penal Code. ${ }^{65}$ Government representatives have from the start stressed off-record that authorities will avoid using the SPCO, and if they do, they will avoid its harshest punishments, reflecting the laws' "educational" orientation and "Islamic mercy." ${ }^{\text {"66 }}$ For apostasy (irtidād), the maximum punishment on paper is stoning, or, if procedural requirements cannot be met, up to thirty years' imprisonment and forty strokes of lashing (SPCO §§ 107-117). But following repentance, the accused must be freed of charges (and, depending on the details of the case, undergo forced "faith counselling") (SPCO § 117, SCCPCO §§ 204-208). Adultery (zinā) and anal sex (liwāt ) cases (SPCO $\S \S 68-81,82-85$ ) require a group of four witnesses of "just" ('adil) character who are practicing Muslims and have seen the act (SPCO § 69(1); Syariah Courts Evidence Order 3(1)) —an unlikely scenario (see also SCCPCO § 173(1)(i)). In murder (qatl) cases (SPCO §§ 124-164) requiring payment of blood money (diyāt) that the accused cannot afford, the Sultan can pay it (SPCO § 133(3)). Confessions (syahadah) pose a problem but can be withdrawn (SPCO §§ 184-190, and SCCPCO First Schedule, pp. 628-633), and authorities claim they would encourage this. Finally, the Sultan can pardon anyone sentenced to death and reinforce his popular image as a "caring monarch." ${ }^{167}$ In short, Brunei's legislation, $\operatorname{sharī~}^{-} a$ and non-sharī $a$ alike, undeniably includes human rights law-violating and authoritarian stipulations, but the mentioned procedural provisions are a key part of the larger scheme, and are frequently referred to in local counter-discourses against international protests.

Existing criminal laws that preceded the new sharī $a$ -

65 How this will be practiced in detail remains to be seen. The author is unclear about the decision-making on which of the two penal codes will be used, and the SPCO and SCCPCO themselves seem to provide no solid answer.

66 I based these observations on various personal communications between 2014 and 2019. On the emphasis of mercy (Arabic: rahma; Malay: rahmat), see Sultan Hassanal Bolkiah cited in Undang-undang, supra note 33.

67 Müller, supra note 2, at 149. 
based Code are mostly justified by the government on national security grounds, such as the Sedition Act and the Internal Security Act; ${ }^{68}$ these laws will continue to be enforced, carrying penalties as harsh as those of the new Islamic laws but without the procedural protections ${ }^{69}$ International attention, however, apparently only arises where tensions with human rights law are linked to the buzzwords "shari ${ }^{`} a$ " and "LGBTQ." Bruneians have been sentenced to caning under the non-shari ${ }^{-} a$ penal code during the SPCO's first period. ${ }^{70}$ Yet this fact was of no interest to international media, whose attention is limited to $\operatorname{sharī~}^{-} a$-based canings. The anthropologist Matthew Erie's notion, made in another context, of the shari ${ }^{-} a$ being a "taboo of modern law," comes to mind. ${ }^{71}$ Furthermore, the Sultan's speech on the moratorium to the death penalty (see Part I) became peculiarly framed by most international media as declaring the death penalty's non-enforcement "on homosexuals" or "for gay sex,"72 although he never mentioned this particular type of SPCO offense. Meanwhile various other SPCO sections, as

68 See Sedition Act of 2010 (Brunei), http://www.agc.gov.bn/AGC\%20 Images/LAWS/ACT_PDF/cap024.pdf [https://perma.cc/G5F4-F62P] and http:// www.agc.gov.bn/AGC\%20Images/LOB/pdf/Internal\%20Security\%20Act $\% 20$ (chapter\%20133).pdf [https://perma.cc/AMY7-73MB].

69 For a prominent case related to the Islamic bureaucracy that unlike other recent cases has been made public, see Fadley Faisal, Defendant in Sedition Trial Flees Before Verdict, Borneo Bull. (Nov. 15, 2018), https://borneobulletin.com.bn/ defendant-in-sedition-trial-flees-before-verdict [https://perma.cc/GF6S-VAJL].

70 See, e.g., Fadley Faisal, 12 Years' Jail, Caning for Thieving Duty Guard, Borneo Bull. (Aug. 4, 2017), https://borneobulletin.com.bn/12-years-jail-caningthieving-duty-guard [https://perma.cc/6CFW-CKH9]; Hakim Hayat, Trio to Learn Fate Soon over String of Housebreaking, Borneo Bull. (Feb. 26, 2017), https:// borneobulletin.com.bn/trio-learn-fate-soon-string-housebreaking [https://perma.cc/ TV76-6T4W].

71 See Matthew S. Erie, Shari 'a as Taboo of Modern Law: Halal Food, Islamophobia, and China, 33 J. L. \& ReLIG. 390 (2019), discussed further on the IsLAMIC LAW BLOG (Apr. 19, 2019), https://islamiclaw.blog/2019/04/19/recent-scholarshiperie-on-\%e1\%b8\%a5alal-food-in-china [https://perma.cc/YZ6R-S3QX].

72 See, e.g., Ben Westcott \& Rebecca Wright, Brunei Backs Down on Gay Sex Death Penalty After International Backlash, CNN (May 6, 2019), https://edition. cnn.com/2019/05/05/asia/brunei-lgbt-death-penalty-intl/index.html [https://perma. cc/FG6X-5BME]; Brunei Will Not Impose a Death Sentence on Homosexuals After Rejection and International Boycott, NewsBeEzer (May 6, 2019), https://newsbeezer. $\mathrm{com} /$ mexicoeng/brunei-will-not-impose-a-death-sentence-on-homosexuals-after-rejection-and-international-boycott [https://perma.cc/S5TJ-J3QY]. 
detailed above, stipulate the same penalty but were of no media interest. The logic behind this selective attention deserves further consideration.

There remain questions. Can Brunei realize the "art of not punishing,"73 which legal historians writing on Islamic criminal law, such as Professor Intisar A. Rabb, show has characterized much of its pre-colonial practice? This is driven by high burdens of proof and the doubt canon-the principle requiring judges to "avoid criminal punishment in cases of doubt."74 Or will the situation gradually become shaped by the "punitive turn" that the legal anthropologist Michael Peletz observes in neighboring Malaysia's sharī $a$ judiciary ${ }^{75}$ These queries remain empirically open questions. Current speculative predictions in either direction tend to be ideological or politically motivated. Time will tell. We must do the work of close research and analysis of Brunei's new laws.

73 Elias Saba, The Art of Not Punishing, Books \& IDEAs (Jan. 11, 2016) (reviewing Intisar A. RabB, DoubT in Islamic Law: A History of Legal Maxims, InTERPRETATION, AND ISLAMIC CRIMINAL LAW (2015)), https://booksandideas.net/TheArt-of-Not-Punishing.html [https://perma.cc/G4GT-3JXN].

74 Intisar A. Rabb, Doubt in Islamic Law: A History of Legal Maxims, Interpretation, AND Islamic Criminal Law (2015); Intisar A. Rabb, The Islamic Rule of Lenity, 44 VAND. J. TransN'L L. 1299 (2011).

75 See Michael G. Peletz, Are Women Getting (More) Justice? Malaysia's Sharia Courts in Ethnographic and Historical Perspective, 52 LAW \& Soc'y Rev. 652 (2018); Michael G. Peletz, A Tale of Two Courts: Judicial Transformation and the Rise of a Corporate Islamic Governmentality in Malaysia, 42 AMERICAN ETHNOLOGIST 144 (2015). 